\title{
"Feminist futures are the seeds we plant today": Building collective power for rights and justice at the 13th AWID Forum
}

\section{Isabel Marler*}

*Correspondence: [imarler@awid.org]

I recently returned from the 13th AWID International Forum, which took place from the 8th to 11th of September 2016 in Bahia, Brazil under the title Feminist Futures: Building Collective Power for Rights and Justice.

Based on a recognition of the complex intersections of power that shape the world, this AWID Forum was not about a particular "issue" but focused on imagining futures free from oppression, injustice, and violence. The event itself was a step in a collaborative journey, led by AWID and its partners, of thinking, planning, outreach, and dialogue that went on for over a year.

This article records some of my reflections from the perspective of my position within AWID's Challenging Religious Fundamentalisms program, drawing on the experience of both the Forum itself and the pre-Forum process, including an International Strategy Meeting we held in Mexico City in February 2016.

I am sure my hybrid positionality comes through in what follows. As a participant-cum-organzier, I have shared my personal experience of this event, but very much from my position inside the organization too.

\section{From the local to the global, and back}

The AWID Forum is the most international of affairs, with participants attending from 120 countries. However, the geographical location of the event was a tangible presence throughout all the discussions we had. That the north-eastern state of Bahia was the setting for the Forum was no accident-the choice of 
location was a political decision based on the long history of struggle in the region, particularly that of Black and Afro-descendent women.

Bahia is home to complex social dynamics around religion not least because it is the home of Candomblé, an Afro-Brazilian religion brought to Brazil from West Africa by people enslaved by the Portuguese ${ }^{1}$. To the tourist, Candomble looks to be celebrated in Salvador's public space, with the shops full of souvenirs showing the symbols of the Orixas (roughly translated as Gods and Goddesses), and shows of traditional dancing and capoeira every evening. But this superficial, often commodified celebration of the religion belies the reality that its followers continue to be violently discriminated against by both the mainstream Catholic establishment, and by many evangelical Churches.

During the Forum, I met Mãe Jaciara Ribeira, a Yalorixá (priestess) of a Candomblé house of worship in the Salvador area. In 1999 a newspaper published a picture of Mãe's mother, also a Yalorixá, along with an article smearing her reputation. Following from the article, Mãe's mother was attacked by a group of evangelical Christians who beat her with a Bible, and after the attack suffered a cardiac arrest that killed her ${ }^{2}$. Mae, or "Mother Jaciara" as she is now known, is an iconic figure in Brazil in the fight against religious intolerance, a struggle which is at once a struggle for religious freedom, racial justice, and gender justice.

Beyond the state of Bahia, the Forum was of course taking place in the midst of the country's so-called "political crisis", in fact a parliamentary coup d-etat ('golpe' in Portuguese). From session to session, chants of 'Fora Temer!' ${ }^{3}$ were heard, from both Braziliant activists, and from others expressing solidarity with their Brazilian colleagues. The situation could not be discussed without reference to religious fundamentalisms. Conservative religious forces were at the forefront of the drive to impeach president Dilma Rouseff, with members of parliament openly dedicating their vote for Rouseff's impeachment to God, 'the family', and even to 'unborn children' (Telesur 2016; Telesur 2016a) 
As the world's largest Catholic country, Brazil is highly influenced by the Vatican's anti-woman stances against sexual and reproductive rights. Meanwhile the rise of evangelical and Pentecostal Churches has seen the ever more mainstream presence of other religious players that also oppose women's autonomy and the rights of LGBTQI people. Maria José "Zeca" Rosado Nunes, of Católicas pelo Direito de Decidir (Catholics for the Rights to Decide, Brazil), an organization that has long been in the forefront of challenging the hierarchy of the Church, described religious fundamentalists as one element in a conjunction of conservative powers-economic, political, and religious - at play in Brazil. She presented a multi-faceted picture of a conservative backlash which is bringing regression in all areas: gender equality, reproductive and sexual rights, civil liberties, racial justice, and economic inequality ${ }^{4}$.

Christian religious groups have an enormous power in the media, with many television channels run by conservative evangelicals. Evangelical groups are also using new technology such as the WhatsApp messaging app to disseminate dogmatic religious ideas. In congress, religious groups exert influence over the law, and in the area of the judiciary. New caps on donations to political candidates in municipal elections, introduced as an anti-corruption measure, have had the unsavoury effect of increasing the successes of those with an independent source of funds - both millionaires and candidates backed by evangelical Churches (Boadle, 2016).

Zeca described how religious groups now focus their efforts not only on the capital Brasilia but also locally; taking advantage of the Federal nature of Brazil, they work to change local laws to roll back sexual and reproductive rights and the rights of LGBTQI people ${ }^{5}$. There has recently been a push for a new law that prohibits school teachers from talking about gender or about equal rights. This infraction, which could be judged on the basis of one anonymous complaint by a student who reports feeling that their 'morality' or 'faith' has been attacked, holds a penalty of 3-6 years in jail. While civil society are continuing to mobilize 
to prevent this law coming to force, it is emblematic of how far conservative religious forces have come in Brazil, that the latter feel they can even propose such a law. Nunes noted that this would not have been imaginable five or 10 years ago ${ }^{6}$.

Of course, the Zika crisis was also a prominent feature in the discussions. Activists from Brazil highlighted the role of religious authorities (and their influence in the health sector) in curtailing their sexual and reproductive rights by proposing that, in response to Zika, women should simply 'avoid falling pregnant', a 'solution' with similarities religiously influenced responses to HIV transmission (Fried 2016; Imam 2016, 29) The strong correlation between public health provision and both race and class was made clear; women living in poverty, racialized women are both disproportionately affected by Zika itself, and suffered the most difficulty in accessing contraceptive and abortion services.

It was clear that the Brazilian situation, while carrying its own historical particularities, had to be viewed as one piece in a global puzzle of rising sectarianism, identitarian religious politics, and ethno-nationalist movements, political polarisation, and the rise/resurgence of 'post-truth' right-wing and fascist politics. When Brazilian activists described conservative groups and individuals feeling emboldened to express hatred against women and minorities more loudly than ever, and with religious dogmatism at the centre of this, participants from various countries drew parallels - from countries in the Middle East and Africa where Islamists have once again taken centre stage, to those dealing with the election of Duterte in the Philippines, to the xenophobia of postBrexit Britain and the Trump presidential campaign. Analysing the structural drivers behind this picture, those present largely agreed that we were seeing the outcome of a number of interrelated crises: widespread neoliberal economic policies, the arms trade and ongoing conflicts, political marginalization, and shrinking democratic spaces. 


\section{Working on Difficult Ground}

Throughout the Forum, some points of tension emerged through our discussions. For example, some of those present felt that the blurring of lines between religion and religious fundamentalisms was problematic, suggesting that a distinction was important to make, either for the purpose of strategic confrontation of religious fundamentalisms, or to ensure respect for people's individual beliefs. Laila Alodaat, of the Women's International League for Peace and Freedom, also expressed concern about the lack of distinction between Muslim/Islamic fundamentalism in particular, and 'violent extremism' as something taking many shapes including right-wing nationalistic movements. From her experiences of international approaches to women in conflict in Syria, she felt that this lack of distinction had led to all conservative religious actors being 'painted with the same brush', thereby alienating grassroots women peace activists who felt that international efforts were targeting their society or culture as a whole. On the other hand, we also heard of the dangers of a distinction between 'violent extremisms' and so-called 'non-violent extremisms', as in the cases of Western governments who, in their 'counter-terrorism' work, have made alliances with and concessions to far-right religious groups that hold abominable views on women.

Many people felt that our analysis should push past a narrow focus on 'fundamentalisms' and interrogate religion as a whole-its institutions, its practices, its presence in the private and personal realms not only in public. Sheena Magenya, of the Coalition for African Lesbians, recalled a story from her personal life: her young son had already begun, through exposure at his nursery classes, to understand the world through a lens of religion, and had told her one day that she 'wasn't a woman of God'. This was a sign, she said, that we must talk about every aspect of religion-as feminists have we not built a movement on the need to address oppressive norms in our 'private' spheres as much as anywhere else? 
This tension was an interesting one. There are many reasons that a distinction between' 'religion' and 'religious fundamentalisms' is more palatable; we feel it has less chance of offending or alienating people, and in certain circumstances we may feel that we have to leave religion alone as a matter of civil liberty. But what is religion if not its ideologies, its practices, and the people who carry out actions in its name? With this accepted, it seems hard to draw a neat line between fundamentalism and 'religion'?

Another tension was the recurrent issue, specifically around Muslim fundamentalisms, of how to balance a need to resist co-optation to other oppressive agendas, while still unequivocally denouncing religious fundamentalisms, and standing in solidarity with those who oppose them. On one hand, some speakers pressed the need to see Western imperialism, military intervention, racist and anti-immigration policies as ventures which have all coopted both feminist language and efforts to resist religious fundamentalisms. Other speakers, however, expressed frustration at over-emphasis on those concerns, at the expense of addressing the realities of religious fundamentalisms. Some expressed a sense of betrayal that feminists, especially those in 'the West', have not shown enough solidarity with those affected and resisting oppressive religious norms. They described Western leftists as being guilty of undermining feminists, especially those with a secular stances, in countries marred by regressive religious norms.

These tensions certainly rang true to my experience of the 'anti-imperialist' efforts in the United Kingdom which, while direly needed, have at times made extremely problematic alliances with religious groups holding regressive worldviews, especially as they pertain to gender. Dominant anti-imperialist narratives also often put forth a binary picture of 'the-West-coloniser' versus 'the-rest-colonized', which does no justice to the intricacies of global and regional power dynamics, and feeds the very victimhood narratives that are a key mobilising tactic of Islamists. At the international level, anti-imperialist narratives 
have been co-opted, along with notions of sovereignty and culturally relativist arguments, to erode hard-won human rights standards as they pertain to women and LGBTQI people (OURs 2017 Trend Report, forthcoming).

I felt glimmers of the excitement that many present were trying to push past the polarization that characterizes this area of discussion, and that the Forum itself was great space for address different 'sides' of this debate at once, but I still got the sense that we were all still somewhat trapped in what Meredith Tax (2012) has called the 'double bind'7 . And I was still left wondering how feminists can find a thorough framework for opposing fundamentalisms in a way that does not feed xenophobia and imperialism, and vice versa. How can we stop seeing these different 'sides' even as sides and start to consistently denounce both imperialism and racism and fundamentalisms as all elements of the same big picture? Do we need to look beyond our existing frames of analysis and find a new political-ethical framework? Or do we have the analysis but find it difficult to translate this into concrete work?

\section{New Thinking and New Ways Forward}

Despite the inevitable tensions, one of the things that struck me most throughout the process leading up to the Forum, and during the Forum itself were the new ways of thinking about gender and religious fundamentalisms that were coming up, and the innovative ways in which activists were already challenging religious fundamentalisms.

We spoke a lot about the links between the rise of fundamentalisms and neoliberalism. We heard local level examples, such as evangelicals in Brazil using drug rehabilitations centres (in the absence of state provision) to spread dogmatism, and discussed the big picture links between our work and military spending, lack of state welfare, and corporate power. I was shown parallels between phenomena I had never linked before, such as between the narco state and drug cartels in Latin America, and the dynamics of fundamentalist armed 
groups in parts of the Middle East. We asked ourselves if religious fundamentalisms would exist if neoliberalism did not.

I was pushed to reflect on the ways in which, although knowing these links, to some extent we fail to work with those doing anti-capitalist work, either because they see our struggle as a 'cultural' one, not linked to their 'structural' work, because they have historically not paid enough heed to interpersonal and gendered violence, or because we ourselves have failed to convert our analysis into concrete collaborative actions. I am still grappling with how activists can make this important cross-movement work happen, in an environment where traction (and funding) often feel dependent on having a clear 'issue' and focus, but the Forum made it clear that this intersectional collaboration must be something we spend more time and energy on as we go forward.

Black and decolonial feminisms were central to discussions throughout the Forum, not least because of the Black Feminisms Forum, an historical pre-Forum event that was held for the first time this year. This perspective also broadened the horizons of my thinking on fundamentalisms.

For example, we are aware the many ways in which the cultural and religious colonialism of Wahhabism has stifled cultural diversity in many Muslim contexts in Africa and Asia denigrating local religious expressions as 'un-Islamic', but we rarely phrase resistance to this as an explicitly anti-colonial struggle. Christian fundamentalists in various African contexts often appeal to notions of "African culture" in anti-homosexuality and misogynist discourse, obscuring the reality that growing regressive religious norms in many African countries are in part fueled and funded by Christian fundamentalists from the USA. And yet, within 'Western' contexts at least, it is not usual to hear people connect up the dots between anti-colonial critique and resistance to this kind of fundamentalism.

The Black feminist perspectives at the Forum provided food for thought on how those working explicitly on fundamentalisms can work more closely with 
Black feminist and anti-/decolonial groups, and vice versa, in order to articulate these struggles in new, more effective ways.

I was inspired by the work of the Coalition of African Lesbians (CAL) seen at the Forum. Their work is unrelentingly intersectional; they refuse to see 'lesbian issues' or 'LGBT issues' as separate from other social injustices. CAL's response to fundamentalisms is that which they describe as the 'think for yourself' strategy. Rather than providing, 'alternative' discourses to counter fundamentalist ideology, CAL's approaches revolve around facilitating discussion about the ideas people subscribe to, asking questions such as "“who does this idea actually belong to?" and "what exactly are your own ideas about this idea?", pushing people to see if they have accepted a societal norm without question. The rationale behind CAL's approach is the understanding that fundamentalisms cannot function in a context of free thought; fundamentalisms are by nature prescriptive of what is acceptable and punishing of dissent. CAL's latest endeavour, the Autonomy Project, explores autonomy as a concept that goes beyond liberal individualist notions of 'choice' that can plague discussions of religion and gender.

The Forum also saw the public launch of the OURs (Observatory on the Universality of Rights), an initiative to monitor initiatives that misuse religion, culture, and tradition to undermine the universality of human rights in the international and regional human rights systems. As well as being the first initiative to do this work in a concerted cross-organizational way, OURs is exciting because it articulates a nuanced intersectional feminist vision of universalism. It insists on the universality of human rights, and resists claims that human rights are a 'western imposition' or an 'imperialist project', whilst recognizing the ways rights discourses have been misused to prop up existing global power inequality, and moving away from one-dimensional liberal constructions of universalism. This project provides one way forward from some of the tensions outlined above through reclaiming universal human rights in a sensitive and intersectional way. 
Beyond these two examples there were many more, such as the Catholics for the Right to Decide network, who provide frameworks which align Catholic religious belief and gender justice to be compatible, while also advocating for secularism from a feminist perspective; the eye-opening artistic strategies of painters, cartoonists, and cabaret performers; work that involved engaging religious leaders but not in ways that ceded them more power, but which disrupted their hegemony while making them advocates for women's rights, to name but a few ${ }^{8}$.

In the lead up to the Forum I had recorded something said by Dawn Cavanagh of CAL as part of an art exhibit we were planning: "we cannot wait for joy, joy is in the struggle itself." This quote returned to me when reflecting on the amazing strategies and frameworks I saw during the Forum process - the most inspiring thing is that this work not only resists the advances of fundamentalisms, or 'pushes back'; it actively building microcosmic versions of the worlds we want, small glimpses of our feminist utopias in the here and now. As Dilar Dirik told us of the Kurdish women's struggle: "We never postpone the future. Feminist futures are the seeds we plant today"

Acknowledgements: With many thanks to those whose conversations and work informed this reflection: Sarah de Roure, Rima Athar, Aline Lemos, and my colleagues Naureen Shameem and Shareen Gokal. Special thanks go to Zeca Rosado Nunes for taking the time to talk to me at length about the situation in Brazil, and to Mãe Jaciara Ribeira for sharing her story.

Isabel Marler is the Communications Coordinator of the Challenging Fundamentalisms programme at the Association for Women's Rights in Development (AWID), and a Research Associate at the Centre for Gender Studies, School of Oriental and African Studies (SOAS, University of London). She previously worked for the transnational solidarity network Women Living Under Muslim Laws (WLUML). She is involved in the British and transnational women's movements, in struggles against austerity and war, and for immigration rights. 


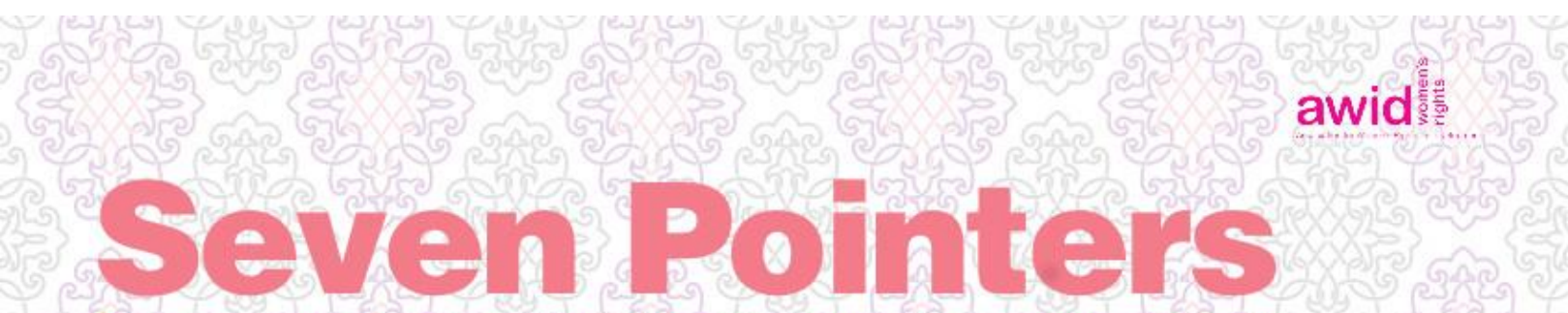

For Development Actors Navigating Religious Fundamentalisms and Women's Rights

\section{Control of women's bodies, sexuality, and choice are "waming signs" of rising fundamentalisms.}

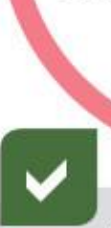

Support alternative economic models that focus on redistribution, state provision of services, and place women's rights and justice at the center of their policies.

Hold states, financial institutions, and corporations accountable for the effects of their policies on human rights and gender justice.
3

\section{Choosing religious organizations as default for partnerships builds their legitimacy and access to resources, and supports their ideology, including gender ideology.}

Take action when women and LGBTQI $^{*}$ people raise the alarm that their freedoms are being eroded.
Don't dismiss women's decreasing freedoms as unimportant or "not the main issue"

Don't wait for fundamentalisms to grow stronger and more embedded in society before you take action. $x$

Don't support development activities that minimize state responsibility for providing services and social safety nets.

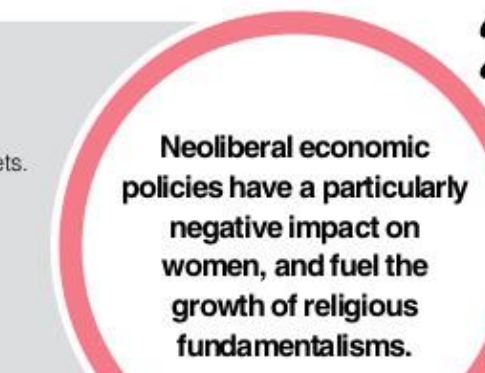

$x$

Prioritize progressive positions on human rights, women's rights, and gender equality when choosing partners for development initiatives. Be sure to thoroughly examine potential partners' views on these topics.

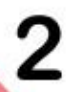

2 icies have a particularly negative impact on women, and fuel the fundamentalisms. 


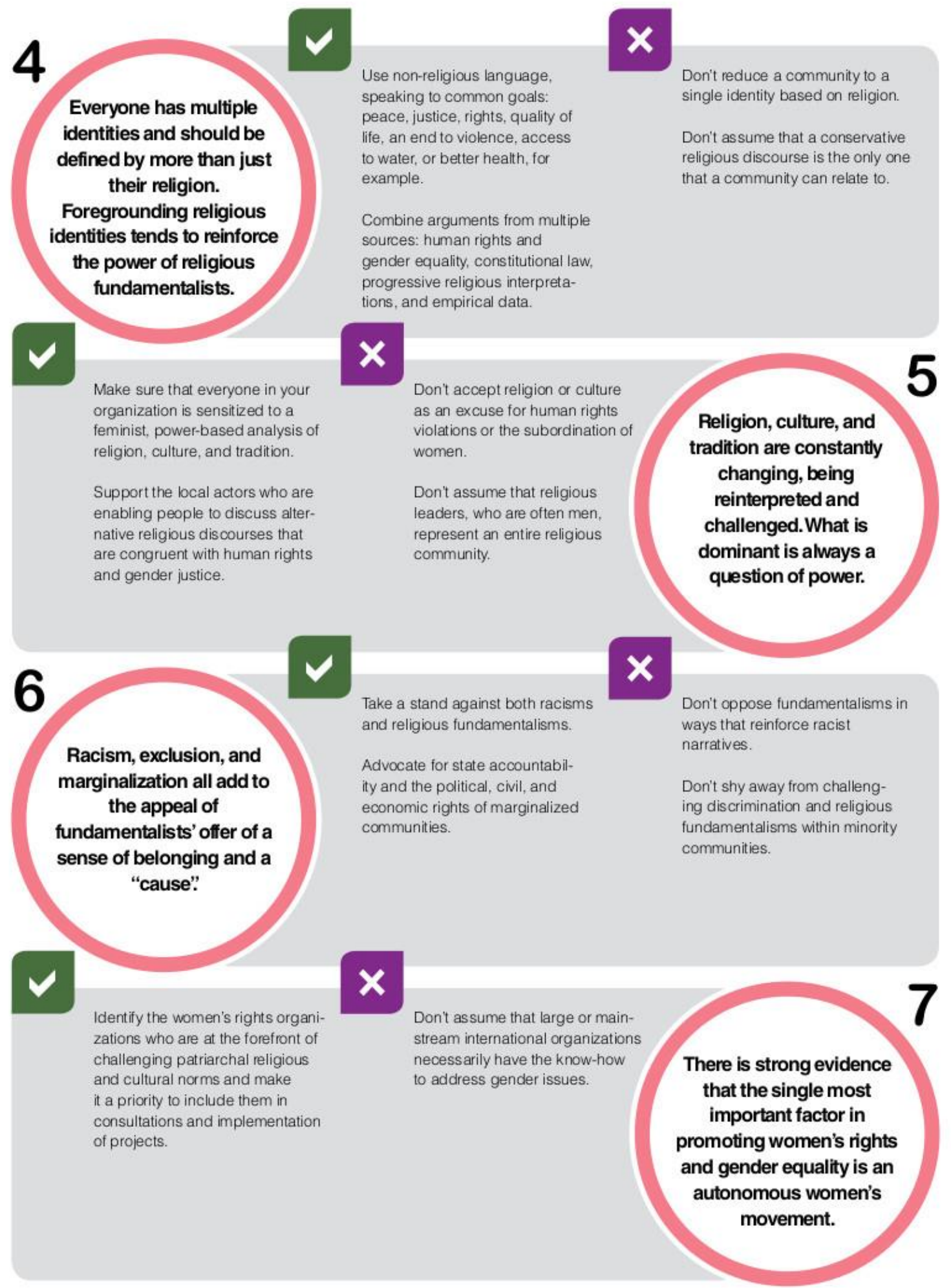

Taken from A. Imam, The Devil is in the Details: At the Nexus of Development, Women's Rights, and Religious Fundamentalisms (AWID, 2016) 


\section{References}

AWID/OURs (forthcoming, 2016), Periodic Report on Anti-Rights Trends at the International Human Rights Level (working title)

Boadle, Anthony, 2016, "Millionaires, evangelicals benefit from Brazil campaign funds ban", Thomson Reuters Foudnation, 29th September 2016

CAL, 2016, "Video: The CAL Autonomy Project: What is Autonomy?" YouTube, 26th September 2016

https://www.youtube.com/watch?v=TXO3yevOjDg

Fried, Susana, "Telling women to avoid pregnancy is not a solution for HIV and the Zika virus", The Guardian, 28th May 2016

https://www.theguardian.com/global-development/2016/may/28/women-avoid-

pregnancy-not-solution-hiv-zika-virus-internation-day-action-womens-health-

conservative-religious-ideologies

Imam, Ayesha, 2016 The Devil is in the Details: At the nexus of Development, Religious Fundamentalisms, and Women's Rights (AWID)

http://www.awid.org/sites/default/files/atoms/files/final web the devil is in the details.pdf

Imam, Ayesha, Isabel Marler, and Laila Malik, "'The Devil is in the Details': development, women's rights and religious fundamentalisms", openDemocracy 50.50, 4th May 2016

https://www.opendemocracy.net/ayesha-imam-isabel-marler-laila-malik/womensrights-development-and-religious-fundamentalisms-devil-

Marler, Isabel, 2016, "12 Activists who will make you hopeful for futures without fundamentalisms" (AWID)

http://www.forum.awid.org/forum16/posts/12-activists-who-will-make-youhopeful-feminist-futures-without-fundamentalisms

Tax, Meredith, 2012, Double Bind: The Muslim Right, The Anglo-American Left, and Universal Human Rights (Centre for Secular Space)

Telesur 2016, "Brazil Evangelical Leaders: Prayers Led to Rousseff Impeachment" 1st September 2016

http://www.telesurtv.net/english/news/Brazil-Evangelical-Leaders-Prayers-Led-to-

Rousseff-Impeachment-20160901-0024.html

Telesur 2016a, "5 Bizarre Reasons Brazil Lawmakers Want to Impeach Dilma" 18th April 2016

http://www.telesurtv.net/english/news/5-Bizarre-Reasons-Brazil-Lawmakers-Wantto-Impeach-Dilma-20160418-0022.html 


\section{Notes}

${ }^{1}$ Candomblé is descended from Yoruba, Fon, and Bantu beliefs brought to Brazil from West Africa. The movement of African slaves to Brazil began midway through the 16th century, with the existing enslavement of indigenous peoples continued well into the 17th and 18th centuries. During the Atlantic slave trade era, Brazil imported more African slaves than any other country. An estimated 4.9 million slaves from Africa came to Brazil during the period from 1501 to 1866.

${ }^{2}$ Interview with Mãe Jaciara Ribeira, Friday 9th September 2016.

${ }^{3}$ Out with Michel Temer, Brazil's new right-wing President who took office after leading the drive for Dilma Rouseff's impeachment.

${ }^{4}$ Interview with Maria José "Zeca" Rosado Nunes of 8th August 2016.

${ }^{5}$ The 26 federate states of Brazil have the power to adopt their own Constitutions and laws, within limits set by the Federal Constitution. Information from interview with Maria José "Zeca" Rosado Nunes, 8th August 2016.

${ }^{6}$ Ibid.

${ }^{7}$ Tax's book Double Bind: The Muslim Right, the Anglo-American Left, and Universal Human Rights

discusses asks how leftists and feminists should respond to human rights violations by the Muslim Right without feeding hate campaigns in a moment of intense xenophobia, focusing on the example of UK organization Cageprisoners.

${ }^{8}$ See Marler, 2016 for a sample of 12 strategies from AWID's partners' work to challenge religious fundamentalisms.

\section{To cite this article:}

Marler, I. (2017). "Feminist futures are the seeds we plant today":

Challenging Fundamentalisms at the 13th AWID International Forum.

Feminist Dissent, 2, 162-175. Retrieved from:

http://journals.warwick.ac.uk/index.php/feministdissent/article/view/56 